\title{
Re-expression of estrogen receptor $\beta$ inhibits the proliferation and migration of ovarian clear cell adenocarcinoma cells
}

\author{
JING ZHU, KEQIN HUA, HONG SUN, YINHUA YU, HONGYAN JIN and YOUJI FENG \\ Obstetrics and Gynecology Hospital at Fudan University, Shanghai 200011, P.R. China
}

Received July 4, 2011; Accepted August 1, 2011

DOI: $10.3892 / o r .2011 .1430$

\begin{abstract}
Ovarian clear cell adenocarcinoma (OCCA) is an aggressive ovarian malignancy with a poor prognosis. The role of estrogen receptor $\beta(E R \beta)$ in the development of OCCA remains to be clarified. To investigate the action of $\operatorname{ER} \beta$ in the proliferation and invasion of OCCA cells, the ES-2 cell line was stably transfected with full-length human ER $\beta$ cDNA, and clones were screened and identified using RT-PCR and Western blot assay. ER $\beta$ stable transfectants, referred to as ES $\beta 1$ and ES $\beta 2$ cells, were compared with mock transfectant ESVE and parental ES-2 cells with respect to their growth, motility and ability to activate target genes. ES $\beta 1$ and ES $\beta 2$ cells expressed ER $\beta$ mRNA and protein, whereas ES- 2 and ESVE cells were ER $\beta$ negative. ER $\beta$ transfectants exhibited distinct characteristics from ES-2 and ESVE cells including proliferative properties and the ability to express cyclin D1 in the presence of $17 \beta$-estradiol $\left(\mathrm{E}_{2}\right)$. ER $\beta$ inhibited ES- 2 cell proliferation, which was determined using the MTT assay, BrdU labeling method and by the down-regulation of cyclin D1 gene expression. Moreover, exogenous ER $\beta$ expression resulted in a significant inhibition of ES-2 cell motility in an in vitro invasion assay. ER $\beta$ reduced the expression of MMP2 mRNA and the activity of MMP2 enzymatic activity in a ligand-dependent manner. In summary, ER $\beta$ may inhibit the proliferation and invasion of ES-2 cells and may be an important regulator in OCCA carcinogenesis.
\end{abstract}

\section{Introduction}

Ovarian clear cell adenocarcinoma (OCCA) has been defined as a distinct histopathological subtype of epithelial ovarian cancer (EOC) by the World Health Organization (WHO) since 1973. OCCA is thought to include $5-10 \%$ of all ovarian carcinoma in Western countries and an even higher percentage in

Correspondence to: Dr Youji Feng, Department of Gynecology, Obstetrics and Gynecology Hospital at Fudan University, 419 Fang Xie Road, Shanghai 200011, P.R. China

E-mail: fengyj4806@sohu.com

Key words: estrogen receptor $\beta$, ovarian clear cell adenocarcinoma, proliferation, invasion, stable transfection
Japan. In an investigation of 28,082 women with EOC, Chan et al reported that 1,411 (5\%) were diagnosed with OCCA, and women with OCCA were younger, more likely to be Asian, and their prognosis was typically worse than serous cancers (1). The clinical management of advanced EOC included maximal cytoreduction and a regimen of platinum-based chemotherapy (2). Pectasides et al reviewed 54 articles concerning OCCA and supported the hypothesis that OCCA was a biologically distinct entity. OCCA patients were found to have a high incidence of stage I disease because it frequently presented with a large pelvic mass. Recurrences of OCCA were more frequent than other types of EOC (3). Patients with OCCA responded poorly to conventional paclitaxel and platinum-based chemotherapy as well as platinum-free chemotherapy.

According to several authors, endometriosis was associated with OCCA in $20-50 \%$ of patients, which is more prevalent than serous adenocarcinoma. Endometriosis-associated early ovarian clear cell adenocarcinoma demonstrated lower tumor proliferation than adenocarcinoma without endometriosis, which indicates differences in their biological characteristics. Mutual interactions mediated through cytokines, such as TGF- $\beta 1$, might occur between endometriosis and OCCA, while endometriosis-derived factors might negatively regulate tumor proliferation (4-6). Akahane et al proposed that a disappearance of steroid hormone dependency might be involved in the malignant transformation of endometriosis into OCCA (7).

The proliferative effect of estrogen has been observed in different estrogen receptor-positive ovarian cancer cells. Syed et al reported that normal and malignant OSE cells exhibited estrogen receptor(ER)-mediated growth stimulatory responses to $17 \beta$-estradiol and estrone. The mitogenic effect of estrogens on OSE cells was mediated through activation of the IL-6/ STAT-3 signaling pathway $(8,9)$. ER $\beta$ might play a protective role against ER $\alpha$ mitogenic activity. Estrogen-induced gene expression through ER $\beta$ may also provide a new therapeutic target (10). These studies introduced the hypothesis that molecular activation of $E R \beta$ or inducing $E R \beta$ re-expression in neoplastic cells may help prevent tumor proliferation or invasion. To help define the role of ER $\beta$ in an ovarian clear cell adenocarcinoma cell line, we introduced full-length human ER $\beta$ cDNA into ES-2 cells. In this study, we investigated growth rates and cyclic changes in the proliferative activity of ES-2 cells and motility mediated by exogenous ER $\beta$ in the ovarian clear cell line. To better determine the molecular 
Table I. Primer sequences for RT-PCR amplification.

\begin{tabular}{lccl}
\hline Target & Base pair & Annealing temperature $\left({ }^{\circ} \mathrm{C}\right)$ & \multicolumn{1}{c}{ Sequences 5'-3' } \\
\hline ER $\beta$ & 259 & 53 & $\begin{array}{l}\text { TGCTTTGGTTTGGGTGATTGC } \\
\text { TTTGCTTTTACTGTCCTCTGC }\end{array}$ \\
GAPDH & 353 & 60 & $\begin{array}{l}\text { GGGAGCCAAAAGGGTCATCATCTC } \\
\text { CCATGCCAGTGAGCTTCCCGTTC }\end{array}$ \\
Cyclin D1 & 482 & 51 & CTGGCCATGAACTACCTGGA \\
MMP-2 & 398 & 55 & GTCACACTTGATCACTCTGG \\
& & & CAGGCTCTTCTCCTTCACAAC \\
& & & AAGCCACGGCTTGGTTTCCTC
\end{tabular}

mechanism underlying the effects of ER $\beta$ modulation, we examined target genes involved in proliferation and invasion of ES-2 cells regulated by constitutive ER $\beta$.

\section{Materials and methods}

Cell lines and culture conditions. Human OCCA ES-2 cells were purchased from the American Type Culture Collection (ATCC, Rockville, USA). Human fibroblast NIH-3T3 cells were gifts from the Breast Cancer Department of Fudan University, China (Shao Zhimin, MD). Cells were cultured in Mc'Coy-5a (Gibco, USA) supplemented with $10 \%$ fetal bovine serum (FBS) in a humidified atmosphere with the presence of $5 \% \mathrm{CO}_{2}$ at $37^{\circ} \mathrm{C}$. Prior to experiments, cells were washed with phosphate-buffered saline (PBS) and maintained in phenol-red free Mc'Coy-5a (Gibco, USA) containing 5\% dextran-coated charcoal (DCC)-stripped FBS (Biological Industries, Israel) and were treated with $10^{-8} \mathrm{M} 17 \beta$-estradiol $\left(\mathrm{E}_{2}\right)$ (Sigma, USA).

Plasmid and stable transfection. The expression plasmid pBK-RSV and the ER $\beta$ cDNA containing plasmid pBK-RSV-ER $\beta$ were obtained from Uniformed Services University of the Health Sciences, Bethesda, USA (Paul H. Driggers, MD) (34). ES-2 cells were seeded into 24-well plates at a density of $5 \times 10^{3}$ per well in Mc'Coy-5a supplemented with $10 \%$ FBS and grown to $90-95 \%$ confluence. Cells were co-cultured with pBK-RSV-ER $\beta$ DNA and Lipofectamine 2000 (Invitrogen, USA) as recommended by the manufacturer. Twenty-four hours after transfection, cells were trypsinized and detached in a $100 \mathrm{~mm}$ petri plate at a 1:10 ratio and cultured in the presence of Geneticin (G418, InvivoGen, USA, $800 \mu \mathrm{g} /$ $\mathrm{ml}$ media). The individual G418-resistant colonies were picked and maintained after two weeks. Expression of ER $\beta$ was verified by RT-PCR and a Western blot assay. A vector control cell line was established by transfecting an empty expression plasmid.

RNA isolation and reverse transcription PCR. Total RNA was isolated using TRIzol (Invitrogen, USA) as recommended by the manufacturer and precipitated with $75 \%$ ethanol using standard procedures. Total RNA $(0.5 \mu \mathrm{g})$ from each sample was subjected to reverse transcription using the M-MuLV Reverse Transcriptase RNase (Fermantas, Canada) and oligo $\mathrm{dT}$ primers (Fermantas) in a $20-\mu 1$ reaction volume. The PCR reactions were performed using $1 \mu \mathrm{l}$ of the RT mixture in a final volume of $25 \mu \mathrm{l}$ with Taq DNA polymerase (Fermantas). To detect ER $\beta$, PCR-amplification involved a denaturation step at $94^{\circ} \mathrm{C}$ for $5 \mathrm{~min}$. Cycles including $45 \mathrm{sec}$ melting at $94^{\circ} \mathrm{C}, 30 \mathrm{sec}$ annealing at $53^{\circ} \mathrm{C}$, and $45 \mathrm{sec}$ of extension at $72^{\circ} \mathrm{C}$ were performed 30 times followed by a final elongation at $72^{\circ} \mathrm{C}$ for $10 \mathrm{~min}$. All PCR primer sequences and reaction conditions are indicated in Table I. The amplified products were separated by electrophoresis on $1.5 \%$ agarose gel and identified by ethidium bromide staining under UV illumination.

Western blot analysis. Cells were grown to 90-95\% confluence on 50-mm petri plates, placed on ice and washed with PBS, lysed in $100 \mu \mathrm{l}$ of a protein extraction buffer $(10 \mathrm{mmol} / \mathrm{l}$ Tris $\mathrm{pH}$ 7.4, $1.5 \mathrm{mmol} / \mathrm{l}$ EDTA, $130 \mathrm{mmol} / \mathrm{l} \mathrm{NaCl}, 1 \%$ Triton, $10 \mathrm{mmol} / \mathrm{l}$ $\mathrm{NaF}, 10 \mathrm{mmol} / \mathrm{l} \mathrm{NaPi}, 10 \mathrm{mmol} / \mathrm{l} \mathrm{NaPPi}, 5 \mu \mathrm{g} / \mathrm{ml}$ aprotinin, $5 \mu \mathrm{g} / \mathrm{ml}$ leupeptin, $100 \mu \mathrm{g} / \mathrm{ml} \mathrm{PMSF}$, and $\left.0.25 \mathrm{mmol} / \mathrm{l} \mathrm{Na}_{3} \mathrm{VO}_{4}\right)$ containing a protease inhibitor cocktail (Roche) and incubated with intermittent mixing for $30 \mathrm{~min}$. Whole cell extracts were collected and debris was removed after centrifugation. Protein concentrations were measured using a protein microassay kit (Shennengbocai, Shanghai, China). Aliquots of $80 \mu \mathrm{g}$ total protein of were separated through $12 \%$ SDS-polyacrylamine electrophoresis gels (Bio-Rad Mini-Gel Box Electrotransfer) and transferred to a PVDF filter (Pall-Gelman, USA). The PVDF filter was developed with primary antibodies (anti-ER $\beta$, Upstate, USA, 1:2000; cyclin D1, Neomarkers, USA, 1:500; $\beta$-actin, Abcam, UK, 1:5000) overnight at $4^{\circ} \mathrm{C}$, blocked in $5 \%$ non-fat dry milk (PBS+0.1\% Tween-20), and incubated with a horseradish peroxidase (HRP)-conjugated anti-rabbit/mouse antibody (1:20000, Qikang, Beijing, China) for $1 \mathrm{~h}$ at room temperature (RT). Proteins were detected using the ECL kit (Pierce Biochemicals, Rockford, IL) and chemiluminescent detection system (Alpha Innotech).

Cell proliferation assay. Two thousand cells were plated in $200-\mu 1$ media per well in a 96 -well plate and incubated $\left(37^{\circ} \mathrm{C}\right.$, $5 \% \mathrm{CO}_{2}$ ) overnight to allow the cells to attach to the wells. Eight wells were left empty for blank controls. Then cells were washed in PBS and cultured in phenol red-free Mc'Coy-5a with 5\% DCC-FBS in the presence of $10^{-8} \mathrm{M} 17 \beta$-estradiol for 1-7 days. The medium was changed every 3 days. A solution of $5 \mathrm{mg} / \mathrm{ml}$ thiazolyl blue tetrazolium bromide (MTT) dissolved 
in PBS was made and filter sterilised through a $0.2-\mu \mathrm{M}$ filter. MTT solution $(20 \mu \mathrm{l})$ was added to each well. The plate was incubated at $37^{\circ} \mathrm{C}$ for $4 \mathrm{~h}$. Media were removed with needle and syringe. Dimethyl sulfoxide $(150 \mu \mathrm{l})$ (DMSO) was added to each well and the plate was placed on a shaking table $(150 \mathrm{rpm}$ for $5 \mathrm{~min}$ ). Optical absorbance (OA value) at wavelength $492 \mathrm{~nm}$ and subtract background at $560 \mathrm{~nm}$ was measured.

BrdU labeling method. Cells were incubated with BrdU (10 $\mu \mathrm{mol} / 1$, Sigma) for $1 \mathrm{~h}$ at $37^{\circ} \mathrm{C}$ and fixed with $4 \%$ paraformaldehyde for $20 \mathrm{~min}$ at room temperature. Following fixation, cells were washed in 0.1 M PBS ( $\mathrm{pH} 7.4)$ (3x5 min) and incubated in $\mathrm{HCl}(2 \mathrm{~N})$ for $1 \mathrm{~h}$ at $37^{\circ} \mathrm{C}$. Immediately after the cells were acid washed, borate buffer $(0.1 \mathrm{M})$ was added for $30 \mathrm{~min}$ at room temperature. Cells were then washed in $0.1 \mathrm{M}$ PBS (3x5 min) and PBS with $1 \%$ Triton X-100 for $2 \mathrm{~min}$ at room temperature. Prior to incubation with anti-BrdU (Sigma, 1:200), cells were blocked with 10\% BSA for $1 \mathrm{~h}$ at room temperature. Following the incubation, the cells were washed in 0.1 M PBS ( $\mathrm{pH} 7.4$ ) with $0.1 \%$ Tween-20 (3x5 min) and were treated with the HRP conjugated secondary antibody to visualize the anti-BrdU-labeled cells with diaminobenzidine (DAB). To measure the labeling index (LI), the following formula was applied: BrdU LI = BrdU labeled cells/total cells counted x $100 \%$.

Gelatin zymography. The running gel (10\%) was prepared with $0.2 \%$ gelatin $(2 \mathrm{mg} / \mathrm{ml})$. The samples were applied (10 $\mu \mathrm{g}$ protein in total medium), and the gel was run with a $1 \mathrm{X}$ Tris-Glycine SDS buffer according to the standard running conditions (100 V, constant voltage). Afterwards, the gels were incubated in a zymogram renaturing buffer (2.5\% Triton $\mathrm{X}-100)$ with gentle agitation for $30 \mathrm{~min}$ at room temperature, washed in a Tris-cl buffer $(50 \mathrm{mmol} / \mathrm{l})$, and replaced with a zymogram developing buffer. The gel was equilibrated for $30 \mathrm{~min}$ at room temperature with gentle agitation and incubated with fresh zymogram developing buffer at $37^{\circ} \mathrm{C}$ for $42 \mathrm{~h}$. Gels were stained with $0.05 \%$ (w/v) Coomassie blue for $24 \mathrm{~h}$ at room temperature, destained for $8 \mathrm{~h}$ in a destaining solution (methanol:aceticacid:water, 10:10:80). Areas of protease activity appeared as clear bands against a dark blue background where the protease had digested the substrate.

Transwell migration assays. Cells $\left(1 \times 10^{5}\right)$ were placed in the upper chamber of 8 micron transwells (Costar, USA) on $100 \mu \mathrm{l}$ of diluted Matrigel (BD Biosciences, Bedford, MA) with NIH 3T3 derived supernatants in the lower chamber and allowed to migrate for 24,48 , or $72 \mathrm{~h}$ at $37^{\circ} \mathrm{C}$. After the appropriate time, the filter side of the upper chamber was cleaned with a cotton swab, and the filter was stained according to the standard H\&E staining procedure. The filter was gently cut from the chamber, and cells that had migrated through the filter pores were counted. Three identical replicates were performed for each migration condition.

Densitometric and statistical analysis. The intensities of mRNA and protein bands of RT-PCR and Western blot assays were determined and calculated in relation to glyceraldehyde3 -phosphate dehydrogenase (GAPDH) mRNA or $\beta$-actin
Positive ES-2 ESVE ES $\beta 1 \quad$ ES $\beta 2$

A ERB

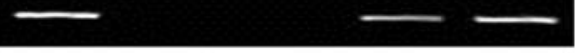

$-259 b p$

B GAPDH

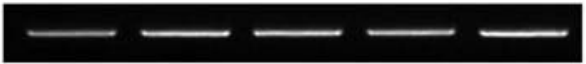

$-353 b p$

\section{ERB}

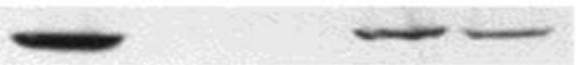

$-59 \mathrm{kDa}$

D $\beta$-actin

$-42 \mathrm{kDa}$

Figure 1. Expression of ER $\beta$ mRNA and protein was analyzed in ES-2, ESVE, ES $\beta 1$ and ES $\beta 2$ cells by RT-PCR (A and B) and Western blot analysis $(\mathrm{C}$ and D). Detection of GAPDH and $\beta$-actin was used as a loading control in both assays. Human testis tissue was used as positive control.

protein levels. Statistical differences were calculated using the $\chi^{2}$ or t-test with SPSS 12.0 software.

\section{Results}

Stable transfection of ES-2 cells with ER $\beta$. To assess the contribution of ER $\beta$ in ovarian clear cell adenocarcinoma and its underlying molecular mechanisms, stable ER $\beta$ transfectants were established. Following antibiotic selection, several clones were identified and screened for ER $\beta$ expression using RT-PCR and Western blot analysis. ES-2 cells used in our experiments were ER $\beta$-negative. Two clones, ES $\beta 1$ and ES $\beta 2$, with high levels of transfected ER $\beta$ expression were chosen for further studies. As a control, ES-2 cells were also transfected with an empty expression vector termed ESVE. RT-PCR products of ER $\beta$ mRNA were detected in transfected ES $\beta 1$ and ES $\beta 2$ cells but not in ES-2 and ESVE cells (Fig. 1A). Western blot analysis confirmed that ES $\beta 1$ and ES $\beta 2$ cells expressed ER $\beta$, while parental ES-2 and mock transfected ESVE cells were ER $\beta$ negative (Fig. 1C). Continued expression of ER $\beta$ was routinely verified throughout the study. ER $\beta$-positive mRNA and protein from human testis were used as a positive control.

Inhibition of ER $\beta$ stable transfectants growth by $E R \beta$ expression. We assessed the growth rate of ES-2, ESVE, ES $\beta 1$ and ES $\beta 2$ cells in vitro using an MTT assay. Initially, a dose-response analysis for $\mathrm{E}_{2}$ was conducted (concentration range: $10^{-5}$ to $10^{-10} \mathrm{M}$ ) (data not shown), and further analyses were performed at an $\mathrm{E}_{2}$ concentration of $10^{-8} \mathrm{M}$. Cells were maintained in steroid-depleted medium containing charcoalstripped $F B S$ and $E_{2}$. After $24 \mathrm{~h}$ of $\mathrm{E}_{2}$ treatment, $\mathrm{ES} \beta 1$ and $\mathrm{ES} \beta 2$ cells began to demonstrate a reduced growth rate compared to ESVE and ES-2 cells. After 7 days, ES $\beta 1$ and ES $\beta 2$ cells showed growth retardation compared to non-transfected and mock-transfected cells (Fig. 2). When cultured in normal medium (i.e., Mc'Coy-5a with 10\% FBS for 7 days), ES $\beta 1$ and ES $\beta 2$ cells also presented growth retardation, although it was less apparent than with $\mathrm{E}_{2}$ treatment. All of the results showed statistical differences in tumor cell growth between ER $\beta$-transfected cells and ER $\beta$-negative cells. 


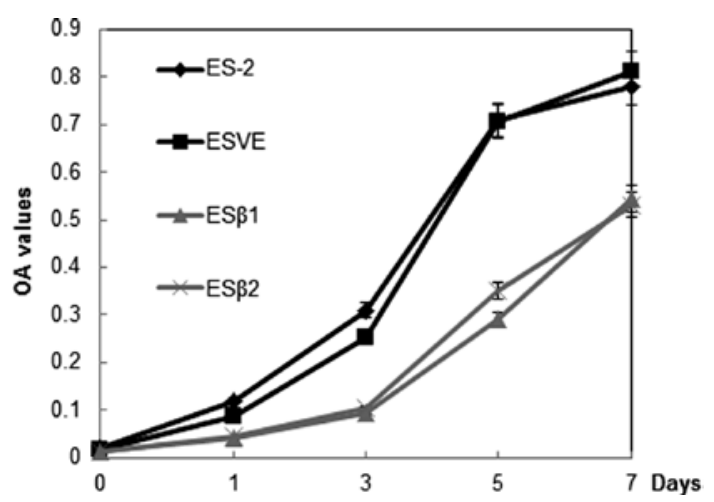

Figure 2. Effect of ER $\beta$-transfection on proliferation of ES-2 cells in vitro. Growth rate was evaluated by MTT assay after 1,3,5 and 7 days of exposure to $10^{-8} \mathrm{M}$ estradiol. ES $\beta 1$ and ES $\beta 2$ cells showed a significantly slower rise in cell numbers than ES-2 and ESVE cells at each selected time. Independent experiment was performed in triplicate. $\mathrm{P}<0.01$.

Effects of ER $\beta$ on cell cycle progression and endogenous target genes. To study the effects of ER $\beta$ on the cell cycle, cells were plated and analyzed using BrdU assays. Fig. 3 shows the BrdU-labeled nucleus of non-transfected, mock-transfected, and ER $\beta$-transfected cells. BrdU LIs of ES- 2 and ESVE cells were $32.03 \pm 1.79$ and $32.20 \pm 1.65 \%$, respectively. The LI of ER $\beta$-transfected ES $\beta 1$ cells was $12.03 \pm 0.81 \%$, which was less than ES-2 and ESVE cells $(\mathrm{P}<0.01)$. No differences in BrdU LI were observed between ES-2 and ESVE cells $(\mathrm{P}>0.05)$.

We analyzed the cell cycle protein cyclin D1, which is associated with proliferative status and S-phase progression. After treatment of ES-2, ESVE, ES $\beta 1$, and ES $\beta 2$ cells with $10^{-8} \mathrm{M} \mathrm{E}_{2}$ for $72 \mathrm{~h}$, the expression of cyclin D1 mRNA and protein was monitored by RT-PCR and Western blot analysis, respectively. Visualization of RT-PCR products by ethidium bromide staining was performed to demonstrate the relative gene expression of cyclin D1 relative to GAPDH. Proteins were detected by Western blot analysis and semiquantified in relation to $\beta$-actin levels. Each experiment was performed independently in triplicate. The expression of mRNA and protein of cyclin D1 was equal in ES-2 and ESVE cells. The cyclin D1 mRNA levels in ES $\beta 1$ and ES $\beta 2$ cells were $50.50 \pm 0.95$ and $50.83 \pm 1.62 \%$, respectively, lower than cyclin D1 mRNA levels in ESVE cells $(\mathrm{P}<0.01)$. The relative protein expression was also lower in ES $\beta 1$ and $E S \beta 2$ cells $(41.00 \pm 2.88$ and $42.47 \pm 1.50 \%$, respectively, lower than the cyclin D1 protein level in ESVE cells, $\mathrm{P}<0.01$ ), as shown in Fig. 4. These results were consistent with the BrdUlabeling analysis and approved the delayed S-phase entry of ER $\beta$-transfected ES-2 cells.

\section{ER $\beta$ exerted influence on the invasion of OCCA}

$E R \beta$ inhibit motility of ES-2 cells. After incubation of cells with $10^{-8} \mathrm{M} \mathrm{E}_{2}$ for 24,48 or $72 \mathrm{~h}$, the total number of ES-2, ESVE, and ES $\beta$ cells that migrated through the membrane was counted in a x200 field under a microscope. Data are reported as the average of experiments for each time setting.

After incubation for $24 \mathrm{~h}$, the numbers of migrating ES-2, ESVE, and ES $\beta$ cells per x200 field were $68.00 \pm 7.00$, $77.33 \pm 8.02$, and $21.67 \pm 5.03$, respectively; after $48 \mathrm{~h}$, the numbers of migrating ES-2, ESVE, and ES $\beta$ cells were $101.67 \pm 7.47,127.67 \pm 15.01$, and $38.33 \pm 9.07$, respectively; after $72 \mathrm{~h}$, the numbers of migrating ES-2, ESVE, and ES $\beta$ cells were $333.00 \pm 25.53,366.00 \pm 26.51$, and $54.33 \pm 14.01$, respectively. Fig. 5 showed that the migration of ER $\beta$ transfected cells was lower than parental ES-2 and mock-transfected cells after 24, 48, and $72 \mathrm{~h}$ of $\mathrm{E} 2$ treatment $(\mathrm{P}<0.01)$. There was no difference in migration between E2-pretreated ES-2 and ESVE cells for each time setting $(\mathrm{P}>0.05)$. These results
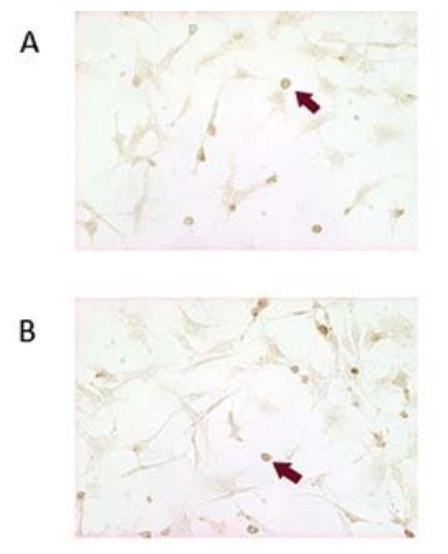

D $\quad$ ES-2 $\approx$ ESVE $\square E S \beta 1$

C

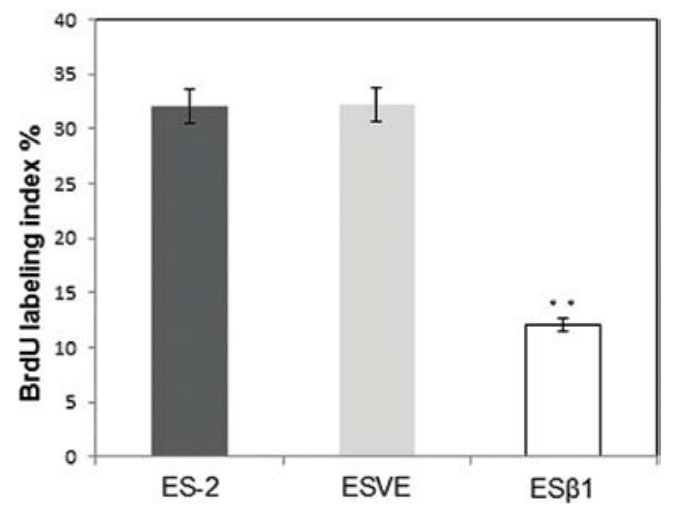

Figure 3. Immunocytological analysis revealed homogeneously stained BrdU-positive nuclei of ES-2, ESVE, and $\beta$-transfected ES $\beta 1$ cells (H\&E staining, x200). (A) BrdU-labeled ES-2 cells; (B) BrdU-labeled ESVE cells; (C) Brdu-labeled ES $\beta 1$ cells; (D) comparison of BrdU labeling index of ES-2, ESVE and ES $\beta 1$ cells. Each experiment was performed in triplicate. ${ }^{* *} \mathrm{P}<0.01$. 


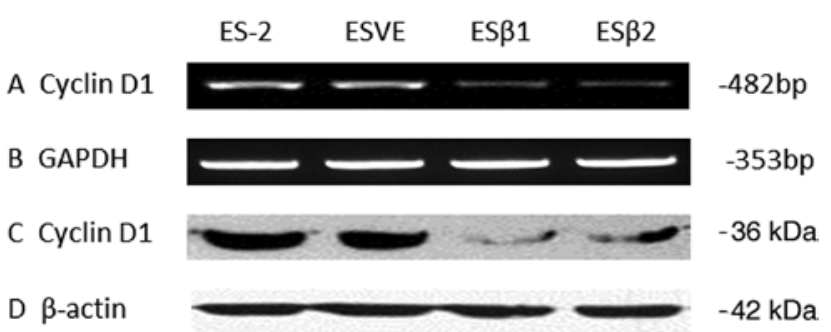

$E$

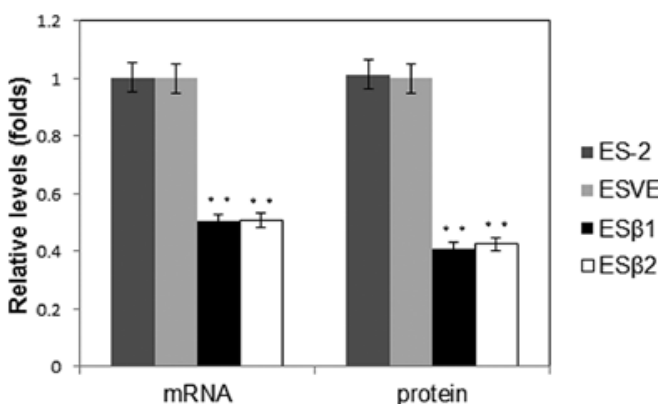

Figure 4. Expression of cyclin D1 mRNA (A) and protein (C) in ES-2, ESVE, ES $\beta 1$ and ES $\beta 2$ cells. (A and B) Illustration of RT-PCR bands of cyclin D1 and GAPDH; (C and D) illustration of Western blot bands of cyclin D1 and $\beta$-actin; (E) semi-quantitative calculation of relative rnRNA and protein expression of cyclin D1 normalized to GAPDH or $\beta$-actin levels. Mean values of relative protein or gene expression were calculated for triplicate experiments. ${ }^{* *} \mathrm{P}<0.01$.

suggested that the expression of $\operatorname{ER} \beta$ decreased the migration of ES-2 cells.

Inverse regulation of $M M P-2$ gene expression and activity by $E R \beta$. After incubation with $10^{-8} \mathrm{M} 17 \beta$-estradiol for $72 \mathrm{~h}$, re-expression of ER $\beta$ caused a decrease in MMP-2 mRNA production in ES $\beta 1$ and ES $\beta 2$ cells compared to mock-transfected ESVE and parental ES-2 cells. The ratios of relative MMP- 2 mRNA band densities of ES $\beta 1$ or ES $\beta 2$ vs. ESVE cells were $25.70 \pm 0.26 \%(\mathrm{P}<0.01)$ and $27.23 \pm 0.75 \%(\mathrm{P}<0.01)$, respectively (Fig. 6A).

Gelatin zymography also showed that MMP-2 activity in culture medium from ER $\beta$ re-expressing cells was far lower than ESVE and ES-2 cells. The active bands for MMP-2 (62 kDa) and proMMP-2 (64 kDa) are shown in Fig. 6C. Gelatinolytic activities of $62 \mathrm{kDa}$ bands were subjected to densitometric analysis, which showed that the activities of MMP-2 were significantly lower in ES $\beta 1$ and ES $\beta 2$ cells (ES $\beta 1$ vs. ESVE, $49.80 \pm 1.35 \%$; ES $\beta 2$ vs. ESVE, $50.77 \pm 1.66 \%$, $\mathrm{P}<0.01)$. Therefore, MMP-2 mRNA production and activity appeared to be negatively regulated by ER $\beta$. These results showed that ER $\beta$ suppressed MMP- 2 mRNA expression of ES-2 cells in a ligand-dependent manner; furthermore, this suppression was reflected in the MMP-2 activity as determined by gelatin zymography, as shown in Fig. 6D.

\section{Discussion}

$\mathrm{ER} \beta$ is a member of the superfamily of nuclear receptors first cloned in 1996 and is highly homologous with the classical functional estrogen receptor $\operatorname{ER} \alpha(11,12)$. ER $\beta$ binds estrogens with an affinity similar to $\mathrm{ER} \alpha$ and mediates estrogen-dependent expression of reporter genes containing estrogen response elements (ERES). ER $\alpha$ and ER $\beta$ can dimerize with each other. Dimerization may increase the complexity of transcription activation and suggests the existence of two previously unrecognized estrogen-signaling pathways, ER $\beta$ homodimers and $\operatorname{ER} \alpha / \operatorname{ER} \beta$ heterodimers. These dimers may cooperate in the regulation of estrogen-
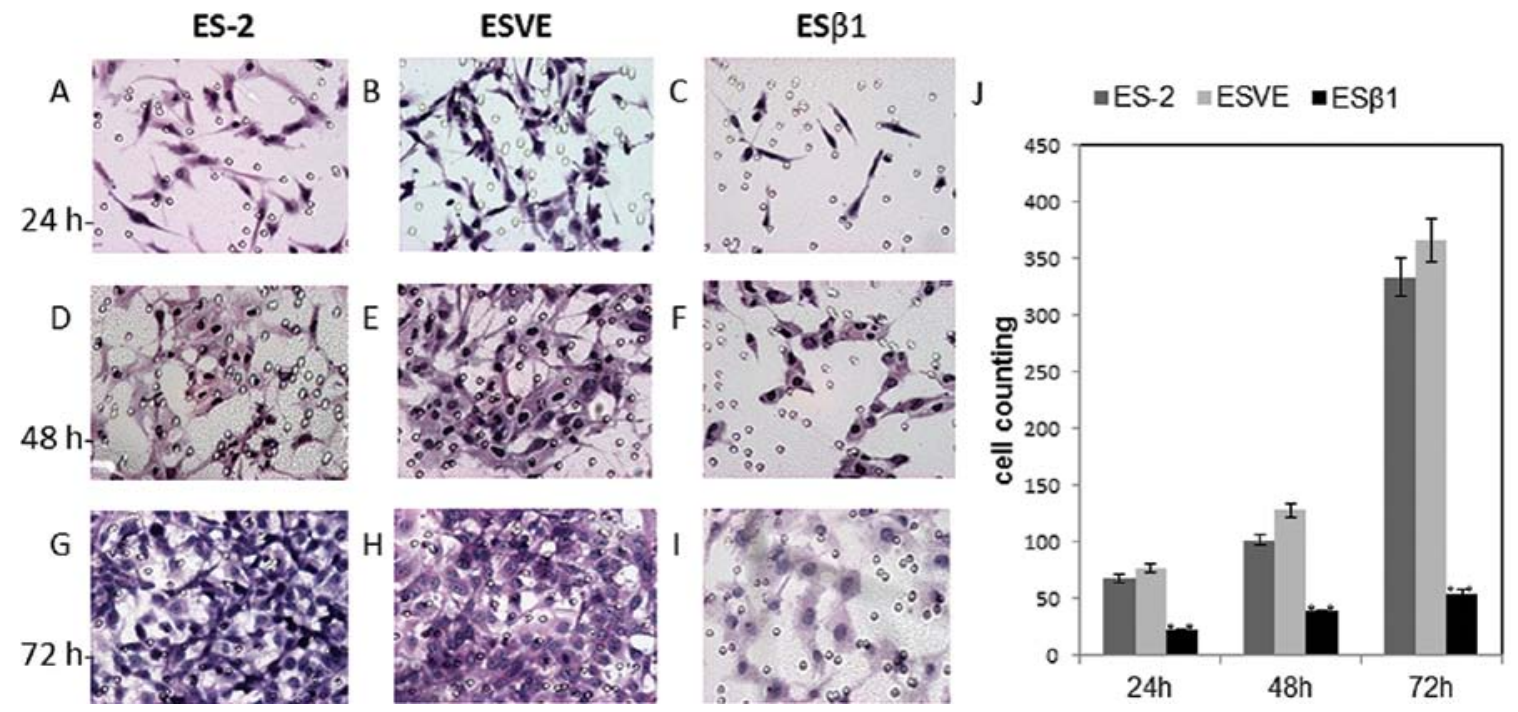

Figure 5. Re-expression of ER $\beta$ reduced Matrigel migration of ES-2 cells with treatment of $\mathrm{E}_{2}$ (H\&E staining, $\mathrm{x} 200$ ). (A) Migrating ES-2 cells for $24 \mathrm{~h}$ transwell assay; (B) migrating ESVE cells for 24-h transwell assay; (C) migrating ES $\beta 1$ cells for 24-h transwell assay; (D) migrating ES-2 cells for 48-h transwell assay; (E) migrating ESVE cells for 48-h transwell assay; (F) migrating ES $\beta 1$ cells for 48-h transwell assay; (G) migrating ES-2 cells for 72-h transwell assay; (H) migrating ESVE cells for 72-h transwell assay; (I) migrating ES $\beta 1$ cells for 72-h transwell assay; (J) the graph represents the average of triplicate experiments for 24, 48, and 72-h. For each time setting, fewer ES $\beta 1$ cells migrated than ESVE cells, while there was no difference in cell counting between ES-2 and ESVE. ${ }^{* *} \mathrm{P}<0.01$. 


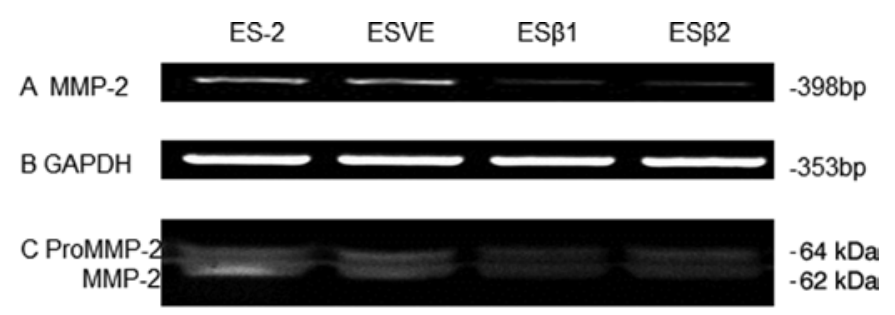

D

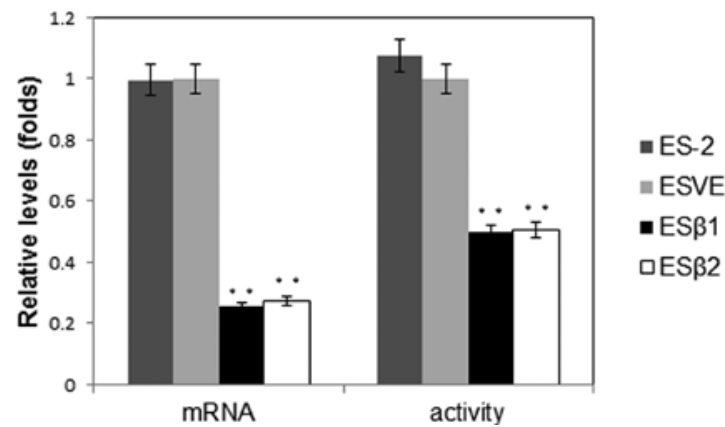

Figure 6 . ER $\beta$ re-expression reduced MMP- 2 mRNA production and activity of ES-2 cells in the presence of E2. (A) RT-PCR production bands of ES-2, ESVE, ES $\beta 1, E S \beta 2$ cells incubated with $10^{-8}$ M $17 \beta$-estradiol for $72 \mathrm{~h}$; (B) the measurement was normalized by the expression of GAPDH; (C) gelatin zymography was performed to show the active bands for MMP-2 (62 kDa) and proMMP-2 $(64 \mathrm{kDa})$ in culture medium $\left(10^{-8} \mathrm{M} 17 \beta\right.$-estradiol, $\left.72 \mathrm{~h}\right)$ from ES-2, ESVE, ES $\beta 1, E S \beta 2$ cells; (D) densitometric analysis indicated that ER $\beta$ suppressed MMP-2 gene transcription and activity in culture medium. Independent experiments were conducted in triplicate. ${ }^{* *} \mathrm{P}<0.01$.

responsive gene expression in cell types in which they are co-expressed (13).

Some evidence has shown that ER $\beta$ may inhibit tumor development and was considered to be a negative dominant of ER $\alpha$. Rutherford et al observed varying amounts of ER $\alpha$ and $\operatorname{ER} \beta$ in normal ovaries, lower levels of ER $\beta$ expression in primary tumors of ovarian epithelial cancer, and only ER $\alpha$ in metastatic tumors. ER $\beta$ mRNA and protein levels decreased in patients with ovarian cancer and metastases (14). Other studies have shown that ER $\beta$ mRNA levels decrease or that the ER $\alpha$ / $\mathrm{ER} \beta$ mRNA ratio increase during ovarian tumor progression (15-17). Other cancers, including breast, prostate and colon, have reduced expression of ER $\beta$ mRNA and/or protein (or an increased ER $\alpha / E R \beta$ mRNA ratio) as well (18-23). The mechanisms involved in the decreased ER $\beta$ expression in tumors remains elusive. The $\mathrm{ER} \alpha / \mathrm{ER} \beta$ ratio is a decisive parameter in orienting the transcriptional mechanism of a target gene in the presence of agonist and antagonist ligands (24). The expression of different gene populations may be affected by the dimer composition of two ER subtypes. The dominant negative properties of ER $\beta$ are mainly due to its AF-1 function.

This study focused on the activities of exogenous fulllength ER $\beta$ cDNA in ES-2 cells (an OCCA cell line, in which $\mathrm{ER} \alpha$ and $\mathrm{ER} \beta$ expression were negative) and transcriptional modulation of target genes in the aggressive cancer cells. One of the most important issues of ovarian clear cell adenocarcinoma is tumor proliferation. Our study provided evidence that ER $\beta$ suppressed the growth of ovarian clear cell adenocarcinoma cells. Transfection of ER $\beta$ into ES- 2 cells resulted in a significant inhibition of cellular growth in vitro and delayed transition into the S-phase of the cell cycle. Growth was further inhibited in an estrogen-dependent manner. Other studies support the idea that decreased ER $\beta$ expression could lead to breast and ovarian cancer development $(15,25,26)$. Furthermore, ER $\beta$ expression in breast cancer cells appears to favor anti-estrogen treatment (24).

As we described, constitutive expression of ER $\beta$ significantly reduced the percentage of cells in the S-phase. To label S-phase cells, bromodeoxyuridine (BrdU), a thymidine analogue, can be incorporated into newly synthesized DNA in S-phase cells. As shown in Fig. 3, transfection of ER $\beta$ into ES-2 cells significantly decreased the BrdU labeling index in an estrogen-dependent manner. To assess the molecular mechanism of the G1-S transition of the cell cycle, we transfected ES-2 cells with ER $\beta$ and observed that cyclin D1 mRNA and protein expression was repressed. This result indicates that constitutive ER $\beta$ might reduce the expression of cell cycle genes, such as cyclin D1, and thus inhibit cell proliferation. $\mathrm{ER} \beta$ has been shown to repress c-myc, cyclin D1, cyclin A, and $\mathrm{Cdk} 2$ and increase the expression of $\mathrm{p} 21$ waf1/cip1 and p27kip1 in MCF-7 breast cancer cells (25,27-29). It also decreased the amount of cyclin E, cdc25A, and p45skp2 in T47D breast cancer cells (30). Furthermore, endogenous ER $\beta$ is one of the mediators of the antiproliferative action of estrogens in enhancing the synthesis of molecules, such as p21, that control the cell cycle in prostate cancer cells (31). All of these observations indicate that ER $\beta$ acts as a tumor suppressor.

Invasion is another important event in highly aggressive ovarian clear cell adenocarcinoma. In this study, we observed that constitutive expression of ER $\beta$ could decrease the migration of ES-2 cells over different time settings. Identification of the mechanism of ER $\beta$ modulation of tumor migration is of considerable interest. Due to its simplicity and sensitivity, gelatin zymography was used for matrix metalloproteinase measurement. MMP-9 and MMP-2 were secreted by cells. MMP-2 and not MMP-9 activity was suppressed on a gelatin zymogram with stable ER $\beta$ transfection. These results, along with decreased MMP-2 mRNA expression in ES $\beta$ cells, indicate that constitutive ER $\beta$ suppresses MMP- 2 expression at the transcriptional level with a subsequent reduction in enzyme protein content. Wound healing-induced migration experiments were performed on ovarian cancer PEO14 cells and it was observed that ER $\beta$-transfected cells had very slow migration ability (15). Decreased migration ability as a result of constitutive ER $\beta$ has also been described previously in breast and prostate cancer $(26,32)$.

Our data provide strong support to the hypothesis that $\mathrm{ER} \beta$ acts as a tumor suppressor in ovarian clear cell adenocarcinoma via its growth-blocking action. The present study demonstrated that stable transfection of an ER $\beta$ isoform into ES-2 cells inhibited the G1-S transition during the cell cycle and reduced cyclin D1 expression. Data from multiple experiments indicate that ER $\beta$ plays an important role in the proliferation of ES-2 cells. It would also be interesting to investigate whether exogenous ER $\beta$ expression in ES-2 cells leads to a difference in motility ability and an associated repression of MMP-2 activity. Our study might provide a more complete understanding of the function of ER $\beta$ and its signal transduction pathway in aggressive ovarian clear cell adenocarcinoma. Re-expression or molecular stimulation of $\operatorname{ER} \beta$ may be a 
potential therapeutic approach. Further studies are necessary to clarify the mechanism of gene modulation (such as methylation of the gene promoter or another transcriptional control) of the $\operatorname{ER} \beta$ signal transduction pathway in carcinogenesis.

\section{Acknowledgements}

We are extremely grateful to Dr Shao Zhimin and Dr Hu Zhen, both from the Breast Cancer department of Fudan University, for their helpful advice and support in all aspects of this study. We also thank Luo Jianmin (Breast Cancer Department, Fudan University, China) for technical assistance. We extend a special thanks to Dr Paul H. Driggers for the generous donation of the ER $\beta$ cDNA expression plasmid (33).

\section{References}

1. Chan JK, Teoh D, Hu JM, Shin JY, Osann K and Kapp DS: Do clear cell ovarian carcinomas have poorer prognosis compared to other epithelial cell types? A study of 1411 clear cell ovarian cancers. Gynecol Oncol 109: 370-376, 2008.

2. Behbakh K, Randall T, Benjamin I, Morgan MA, King S and Rubin SC: Clinical characteristics of clear cell carcinoma of the ovary. Gynecol Oncol 70: 255-258, 1998.

3. Pectasides D, Pectasides E, Psyrri A and Economopoulos T: Treatment issues in clear cell carcinoma of the ovary: a different entity? Oncologist 11: 1089-1094, 2006.

4. Komiyama S, Aoki D, Katsuki Y and Nozawa S: Proliferative activity of early ovarian clear cell adenocarcinoma depends on association with endometriosis. Eur J Obstet Gynecol Reprod Biol 127: 130-136, 2006.

5. Komiyama S, Aoki D, Tominaga E, Susumu N, Udagawa Y and Nosawa S: Prognosis of Japanese patients with ovarian clear cell carcinoma associated with pelvic endometriosis: clinicopathologic evaluation. Gynecol Oncol 72: 342-346, 1999.

6. Nezhat F, Datta MS, Hanson V, Pejovic T, Nezhat C and Nezhat C: The relationship of endometriosis and ovarian malignancy: a review. Fertil Steril 90: 1559-1570, 2008.

7. Akahane T, Sekizawa A, Okuda T, Kushima M, Saito H and Okai T: Disappearance of steroid hormone dependency during malignant transformation of ovarian clear cell cancer. Int J Gynecol Pathol 24: 369-376, 2005.

8. Syed V, Ulinski G, Mok SC, Yiu GK and Ho SM: Expression of gonadotropin receptor and growth responses to key reproductive hormones in normal and malignant human ovarian surface epithelial cells. Cancer Res 61: 6768-6776, 2001.

9. Syed V, Ulinski G, Mok C and Ho SM: Reproductive hormone induced, STAT3-mediated interleukin 6 action in normal and malignant human ovarian surface epithelial cells. J Natl Cancer Inst 94: 617-629, 2002.

10. Cunat S, Hoffmann P and Pujol P: Estrogens and epithelial ovarian cancer. Gynecol Oncol 94: 25-32, 2004.

11. Mosselman S, Polman J and Dijkema R: ER $\beta$ : identification and characterization of a novel human estrogen receptor. FEBS Lett 392: 49-53, 1996.

12. Kuiper GGJM, Enmark E, Pelto-Huikko M, Nilsson S and Gustafsson JÅ: Cloning of a novel estrogen receptor expressed in rat prostate and ovary. Proc Natl Acad Sci USA 93: 5925-5930, 1996.

13. Pace P, Taylor J, Suntharalingam S, Coombes RC and Ali S: Human estrogen receptor $\beta$ binds DNA in a manner similar to and dimerizes with estrogen receptor $\alpha$. J Biol Chem 272 : 25832-25838, 1997.

14. Rutherford T, Brown WD, Sapi E, Aschkenazi S, Muñoz A and Mor G: Absence of estrogen receptor- $\beta$ expression in metastatic ovarian cancer. Obstet Gynecol 96: 417-421, 2000.
15. Bardin A, Hoffmann P, Boulle N, Katsaros D, Vignon F, Pujol P and Lazennec G: Involvement of estrogen receptor $\beta$ in ovarian carcinogenesis. Cancer Res 64: 5861-5869, 2004.

16. Lindgren PR, Cajander S, Bäckström T, Gustafsson JA, Mäkelä S and Olofsson JI: Estrogen and progesterone receptors in ovarian epithelial tumors. Mol Cell Endocrinol 221: 97-104, 2004.

17. Pujol P, Rey JM, Nirde P, Roger P, Gastaldi M, Laffargue G, Rochefort $\mathrm{F}$ and Maudelonde T: Differential expression of estrogen receptor- $\alpha$ and $-\beta$ messenger RNAs as a potential marker of ovarian carcinogenesis. Cancer Res 58: 5367-5373, 1998.

18. Roger P, Sahla ME, Mäkelä S, Gustafsson JA, Baldet P and Rochefort H: Decreased expression of receptor beta protein in proliferative preinvasive mammary tumors. Cancer Res 61: 2537-2541, 2001.

19. Skliris GP, Munot K, Bell SM, et al: Reduced expression of oestrogen receptor beta in invasive breast cancer and its re-expression using DNA methyl transferase inhibitors in a cell line model. J Pathol 201: 213-220, 2003.

20. Fixemer T, Remberger K and Bonkhoff H: Differential expression of the estrogen receptor beta in human prostate tissue, premalignant changes, and in primary, metastatic, and recurrent prostatic adenocarcinoma. Prostate 54: 79-87, 2003.

21. Horvath LG, Henshall SM, Lee CS, et al: Frequent loss of estrogen receptor-beta expression in prostate cancer. Cancer Res 61: 5331-5335, 2001

22. Campbell-Thompson M, Lynch J and Bhardwaj B: Expression of estrogen receptor (ER) subtypes ER beta isoforms in colon cancer. Cancer Res 61: 632-640, 2001.

23. Foley EF, Jazaeri AA, Shupnik MA, Jazaeri O and Rice LW: Selective loss of estrogen receptor beta in malignant human colon. Cancer Res 60: 245-248, 2000.

24. Gougelet A, Mueller SO, Korach KS and Renoir JM: Oestrogen receptors pathways to oestrogen responsive elements: the transactivation function-1 acts as the keystone of oestrogen receptor (ER) $\beta$-mediated transcriptional repression of ER $\alpha$. J Steroid Biochem 104: 110-122, 2007.

25. Behrens D, Gill JH and Fichtner I: Loss of tumourigenicity of stably ER $\beta$-transfected MCF-7 breast cancer cells. Mol Cell Endocrinol 274: 19-29, 2007.

26. Lazennec G, Bresson D, Lucas A, Chauveau C and Vignon F: ER beta inhibits proliferation and invasion of breast cancer cells. Endocrinology 9: 4120-4130, 2001.

27. Paruthiyil S, Parmar H, Kerekatte V, Cunha GR, Firestone GL and Leitman DC: Estrogen receptor beta inhibits human breast cancer cell proliferation and tumor formation by causing a G2 cell cycle arrest. Cancer Res 64: 423-428, 2004.

28. Liu MM, Albanese C, Anderson CM, et al: Opposing action of estrogen receptors alpha and beta on cyclin D1 gene expression. J Biol Chem 277: 24353-24360, 2002.

29. Omoto y, Inoue S, Ogawa S, et al: Clinical value of the wild-type estrogen receptor beta expression in breast cancer. Cancer Lett 163: 207-212, 2001.

30. Ström A, Hartman J, Foster JS, Kietz S, Wimalasena J and Gustafsson JA: Estrogen receptor beta inhibits 17beta-estradiolstimulated proliferation of the breast cancer cell line T47D. Proc Natl Acad Sci USA 101: 1566-1571, 2004.

31. Pravettoni A, Mornati O, Martini PGV, Marino M, Colciago A, Celotti F, Motta M and Negri-Cesi P: Estrogen receptor beta (ERbeta) and inhibition of prostate cancer cell proliferation: studies on the possible mechanism of action in DU145 cells. Mol Cell Endocrinol 263: 46-54, 2007.

32. Cheng J, Lee EJ, Madison LD and Lazennec G: Expression of estrogen receptor beta in prostate carcinoma cells inhibits invasion and proliferation and triggers apoptosis. FEBS Lett 566: $169-172,2004$.

33. Driggers PH, Segars JH and Rubino DM: The proto-oncoprotein Brx activates estrogen receptor beta by a p38 mitogen-activated protein kinase pathway. J Biol Chem 276: 46792-46797, 2001. 